\title{
Pediatric Cardiology in The Past, Present, and Future: Its Role in The Prevention and Management of Cardiovascular Disease
}

\author{
Bambang Madiyono
}

(Department of Child Health, Medical School, University of Indonesia, Jakarta)

The title mentioned above is chosen in a consideration that we are now entering the Second Stage Long-Term Development Plan (or PJP-II), even the Sixth Five-Year Development Plan is being passed in part. This is a stage of quality and productivity improvement of our human resources for the sake of developmental success to achieve a fair and wealthy society based on the Pancasila and the Constitution of 1945. In his presidential speech before the General Meeting of People's Advisory Assembly or MPR on Friday, Aug. 16, 1996, President Soeharto declared that: "The service of public health has been continuously improving. Various efforts in the medical sector has already reduced the infant mortality, increased the life expectancy, reduced the population growth, and improved the quality of other physical and spiritual life."1

On the other side, cardiovascular disease, according to the Indonesian Household Health Survey of 1996, has become a major problem, with high morbidity and mortality. ${ }^{2}$ It is this critical condition that made a starting point to this discussion. I hope that this following discussion can be seen as a contribution in the development of pediatrics, especially in pediatric cardiology, for the benefit of our nation progress in raising the quality of our human resources in order to face the era of globalization. ${ }^{3}$

\section{Pediatric Cardiology as a Subspecialty}

Pediatric cardiology develops pediatrics together with 14 other subspecialties (allergic immunology, endocrinology, gastroenterology, intensive care, nutrition, hepatology, hematology, tropical infection, nephrology, neurology, imaging, perinatology,.pulmonology, and social pediatrics). The promotion of pediatrics and the improvement of

\footnotetext{
- Abridged from Professional Ineuguration, Medical School, University of Indonesia, jakarta, June 1997. Author's address: Bambang Madiyono, MD, Department of Child Health. Medical School, University of Indonesia, Jakarta 10430.
} 
pediatric specialist's professionalism are urgently required in order to achieve the quality of child growth optimally in line with his genetic potential, which in turn will improve human resources.

One of the main aims of pediatrics has been the optimalization of child health standard through preventing as well as managing various illness by the 15 subspecialties, including pediatric cardiology. In the treatment of infants and children, it must be understood that they are not little adults. In addition to their regeneration capacity at cellular, molecular, and humoral levels which is highly different with that of adults, the pattern of their development in each phase is not linear. One thing that is same as in adults is that every cardiovascular disease and its sequelae in infants and children must be managed holistically and comprehensively, by applying all aspects of medication in accordance with the general principles of patient management. Thus, infants and children with cardiovascular disease require thorough treatment, including treatment of various aspects beyond cardiovascular problems.

The prevention and treatment of cardiovascular disease and its sequelae, such as cyanotic and non-cyanotic congenital malformations in infants and children have been an important aspect in pediatric cardiology. In addition, rheumatic fever and rheumatic heart disease are currently still prevalent in Indonesia. Furthermore, nonrheumaúc heart disease accompanying or complicating of metabolic or nutritional disturbance, immunologic diseases, blood diseases, nervous disorders, lung diseases, and so on remains to be an important aspect. Various cardiovascular complications in infants and children, such as cyanotic lesions, pulmonary hypertension, cardiac failure, infective endocarditis, dysrhythmias, and cardiac arrest, need to be detected earlier and treated adequately. Pediatric cardiology also plays a significant role in preventing cardiovascular diseases manifested in adults, such as coronary heart disease and essential hypertension. The role, however, is not limited to the avoidance of risk factors, but also includes anticipatory efforts before childhood and adolescence. Accordingly, the role of pediatric cardiology must be a continuous process from conception, fetal life, infancy, childhood to adolescence.

From the beginning, pediatric cardiology is directed toward the infant below 1 year of age, where morbidity and mortail - from congenital heart disease are the highest. This condition underlines the demand for : xediatric cardiologist' professionalism with a strong basic knowledge in the biomedical sciences associated with cardiovascular problems, such as biology, physiology, histology, anatomy, pathophysiology, histopathology, microbiology, clinical pathology, and hydraulics of cardiovascular system. In addition, the capability of clinical skills in the cardiovascular system is also important. Performing and interpreting electrocardiographic, phonocardiographic, vectorcardiographic, cardiovascular radiology, echocardiographic, cardiac catheterization, angiocardiographic and nuclear cardiologic examinations, both for diagnostic and therapeutic purposes, in infants and children are mandatory. This clinical capability can be achieved by providing training to pediatricians and cardiologists interested in pediatric 
cardiology. In several developed countries, such as in United Kingdom, United States, Australia, and New Zealand, the qualification is obtained through an intensive training in pediatric cardiology for two years or more. ${ }^{4-11}$

Thus, an unavoidable expertise dichotomy in cardiology, between pediatric cardiologists and adult cardiologists is established in the most developed countries because of the continuous development mentioned above. At the present time, peciatric cardiologists have minimal capacity in caring patients with coronary heart disease; on the other hand, adult cardiologists know very little in managing infants and children with congenital heart disease. ${ }^{4}$

\section{Development of Pediatric Cardiology: A Brief Flashback}

The development of modern pediatric cardiology begins from the work of Dr. Maude $\mathrm{E}$. Abbott, a Canadian physician. Her important contributions to pediatric cardiology over a number of years culminated in 1936 with the publication of her monumental book, The Atlas of Congenital Heart Disease. Subsequently, many clinicians, stimulated by Abbott's contributions, began to develop the clinical diagnosis of congenital heart defects in more specific way.

Although a congenital malformations of the heart now known as tetralogy of Fallot had been reported previously by many researchers, it was Fallot who was the first to describe its pathologic and clinical correlation in 1888. All of these pathologic and clinical descriptions were limited to academic interest only, since there was no available treatment. The investigation of congenital malformations was disregarded by a large number of medical practitioners at that time, whose role was limited to matters of general advice and prognosis. It is reflected in the 1100 pages first textbook on pediatrics written by Dr. Thomas Morgan Roch in 1896, where congenital diseases of the heart was described only in 7 pages.

Robert Gross, a junior pediatric surgeon, made a medical history in 1938 by his first successfully attempt to ligate ductus arteriosus ligation in $7 \frac{1}{2}$-year-old girl in Boston. It was performed with the encouragement of J. P. Hubbard, a pediatrician, and without the permission of his chief who was on leave. Blalock and Taussig in 1944 demonstrated that subclavian artery-to-pulmonary artery anastomosis improved the oxygenation of the cyanotic patient by providing more blood flow to the lungs.

A major forerunner in the development of pediatric cardiology was Dr. Helen B. Taussig, Director of the Children's Cardiac Clinic at Johns Hopkins University. She drown herself on pediatric cardiology by making clinical observations to elucidate the correlation between the diagnosis, pathophysiology, and natural history of practically all congenital malformations of the heart, in particular cyanotic malformations with decreased pulmonary blood flow. She initiated the subclavian-pulmonary artery anastomosis as a mean of surgical palliation that she described in detail in her classical 
first edition of the book entitled Congenital Malformations of the Heart in 1947.

Subsequently, a number of research and training programs were created throughout America and Europe. One of prominent pediatric cardiologists was Dr. Alexander Santos Nadas, a Hungarian origin physician. He was the student of Dr. Paul Wood of England. In the peak of his career, Nadas successfully trained more than 150 pediatric cardiologists at the Children's Hospital in Boston, published a number of journals and textbooks, and chaired various professional organizations. Descriptions on circulatory hemodynamics using schematically cardiac images was characteristic of him. In order to appreciate Nadas' contributions, Dr. Donald C. Fyler, one of his students and colleagues, published Nadas' Pediatric Cardiology in 1992. In the foreword of the book, Dr. Nadas suggested, "organizationally, the majority of pediatric cardiologists come from pediatrics, not from cardiology. By contrast, pediatric cardiac surgeons, with notable exceptions, come from cardiac surgery, not pediatric surgery." ${ }^{2}$ "There were still many pediatric cardiologists who made their contributions to the development of pediatric cardiology, among others Drs. Arthur J. Moss, Forrest H. Adams, J. K. Perloff, D. Mc Namara, Arthur Garson, R. H. Anderson, Edward Clark, and Atsuyoshi Takao, ${ }^{4-13}$

\section{Cardiac Surgery as The Main Partner of Pediatric Cardiologist}

Undoubtedly, the improvement of cardiac surgical techniques were in conjunction with the advances in pediatric cardiology. The use of deep hypothermia and circulatory arrest in the late 1960 s, developed initially in Japan by Dr. Mori and perfected in New Zealand by Dr. Brian Barratt-Boyes and his group, made possible primary repair of congenital cardiac defects in early infancy without the need of prior palliative operations. The deep hypothermia approach refined further during the 1970 s, by introducing low level body perfusion and improvements in myocardial preservation by cardioplegia, made possible safe primary reparative or palliative surgery of smaller infants with more complex cardiac malformations. At about.the same time, Dr. Aldo R. Castaneda introduced the protection principles of myocardium and brain during surgery as well as cardiac surgery techniques. ${ }^{14}$

One of the most difficult-to-treat cyanotic cardiac malformations has been transposition of the great arteries with intact ventricular septum. This defect in general is invariably lethal unless a native intraatrial communication exists or is created surgically. Inspired by this, Dr. William Rashkind of Philadelphia developed the lifesaving technique of balloon atrial septostomy (Rashkind procedure). This emergency technique, introduced in the late 1960 s, enabled a large number of neonates with the malformation to survive, rendering them candidates for subsequent intra-atrial switch operations (i.e., Senning or Mustard procedures). With the continuous development of new surgery techniques in the last 10 years, arterial switch operations is more used than intraatrial ones.

After initiating the lifesaving technique of balloon atrial septostomy, Dr. Rashkind 
introduced the closure of patent ductus arteriosus and secundum atrial septal defect using special devices of cardiac catheterization. Dr. Rashkind should be regarded the father of therapeutic interventional pediatric cardiology for his pioneering work. At present, his techniques are being developed and used in many cardiologic centers. Patent ductus arteriosus can be treated using coils, while intracardiac defects using buttoned devices. Arterioclerosis, temporarily treated with the performance of balloon atrial septostomy, can be effectively treated using intravascular stents. ${ }^{15}$

\section{The Role of Echocardiographic Examination}

Echocardiographic examinations experienced a very rapid progress during the last 15 years, revolutionizing the diagnostic approach and management of congenital heart disease. All information on anatomic and hemodynamic abnormalities could be assessed by sophisticated echocardiographic devices with remarkable clarity and safety. Consequently, senior pediatric cardiologists with older diagnostic approaches in habit acquired more confidence in the images they were seeing, but younger pediatric cardiologists were unsure without them. On one hand, it was an obligation to younger pediatric cardiologists to able to use the echocardiographic devices. On the other hand, they were unable to develop clinical diagnostic abilities based on physical examinations, such as observation, palpation, percussion and auscultation of the patient. It was not a surprise if pediatric cardiologists without stethoscope may be born in the future.

The role of diagnostic cardiac catheterizations has been significantly reduced up to $30-40 \%$, due to the application of increasingly sophisticated echocardiographic devices. However, the total number of cardiac catheterization procedures still remains in many centers, due to the increased functions in therapeutic interventions including electrophysiologic examinations and arrhythmia therapy using high-frequency ablation. Advances in electrophysiology and pacemaker technology are blessing for the infants and children with postoperative arrhythmias. Highly sophisticated miniaturzed pacemaker devices are available now for the infants with congenital or acquired heart block. Arrhythmia types that unresponsive to drug therapy, like persistent supraventricular tachycardias, can also be treated by surgical and high-frequency ablation techniques.

A number of pediatric cardiologists and obstetricians have begun put their interest in the development of prenatal diagnosis in line with the increasing progress of echocardiographic technology. One of them who was also attracted to fetal echocardiography, a woman again, was Dr. Lindsey D. Allan. Complex cardiac malformations can be detected as early as 16 weeks gestation by using fetal echocardiographic examinations, so that the pregnancy termination could be taken into consideration. In addition, sequential fetal echocardiographic examinations are also useful to: (i) providing 
insight into the pathogenesis of congenital heart defects; (ii) assessing physiologic and anatomic features of the fetal circulation during fetal growth; (iii) providing important information on cardiovascular abnormalities due to chronic hypoxia; and (iv) detecting earlier fetal disturbances in order to determine the appropriate delivery.

Recently, research in molecular biology and genetics relating to orderly structure and function of the heart is developed, so that more detail information regarding both the pathogenesis of congenital malformations and early control possibilities of congenital disease of adulthood can be obtained. ${ }^{16}$

\section{Preventive Cardiology: An Important Aspect of Pediatric Cardiology In The Future}

It is clear that the role of the pediatric cardiology in the prevention of hypertension and coronary heart disease is significant, although it has been debated among medical experts. Some maintain the prevention of coronary heart disease since infancy is only absolutely needed to the children with familial hypercholesterolemia, while a large number of them recognize that dietary interventions, avoidance of smoking, and regularly exercise are recommended as a means of preventing development of atherosclerosis.

Nowadays, our market is flooded by drugs with highly content of Omega 3 especially derived from cod-liver oil (EPA/C20:5), one of polyunsaturated fatty acids (PUFAs) that has an effect in reducing low-density lipoprotein (LDL) cholesterols and antithrombogenic, that is lowering the thrombosite aggregation. ${ }^{17}$ Unfortunately, however, such thing is out of the reach of most people due to its relatively high prices. Meanwhile, there are so many meals in the form of fast food worldwide, including in developing countries, that contain high protein and calorie but its nutritient value is unequal because of higher content of saturated fatty acid (SFA) and lower content of Omega 3. This kind of food, found mostly in Western-style restaurants such as McDonald's, Kentucky Fried Chicken, California Fried Chicken and so on, mushrooms everywhere, even in corners of the village. There is evidence that LDL cholesterol level in childhood have a close correlation with dyslipidemia and cardiovascular risks in adulthood. ${ }^{18}$

As a matter of fact, people only require a balanced menu to consume using relatively cheap foodstuffs, such as cooked rice, vegetables, tofu, tempeh, and fish. In this case, one should take higher content of nutrient, calories, low-density fatty, animal and vegetable proteins, as well as vitamin into account. Omega 6 (linoleic acid, C18:2), one of PUFAs belongs to essential fatty acid type, is significant for the growth and development of cells and brain tissues in infants and children. Consumption of carbohydrate, SFA, and Omega 6 in larger amount, unless there is a family history of hyperlipidemia, is begin to restricted when the child age above 18 years old. Although its results are not proven as yet, salt intake restriction and regularly aerobic exercise are 
recommended by a large number of experts for children with blood pressure above the 95th percentile and a family history of hypertension. ${ }^{4}$

The avoidance of smoking also required a serious attention of each countries, particularly of developing countries. The fact remains that smoking prohibition is more strict in developed countries than in developing countries. ${ }^{19}$ An alarming situation from day to day is that younger people have begun to smoke due to, among others, the influence of cigarette ad and prestige. It is performed regardless the long-term impacts of this bad habit, which is dangerous not only for smokers, but also for their community and environment. Apparently, the motto of "to make health society's heart and to socialize healthy heart" is still a mere slogan. The motto needs to be propagated in society, in particular in developing countries, through cross-sectoral efforts. In this case, it is hoped that the government and professional organizations will interfere immediately in regulating the restriction of ad involvement in sport events associated with cigarettes. ${ }^{20}$

\section{Pediatric Cardiology in Indonesia}

The development of pediatric cardiology in Indonesia, particularly in Jakarta, has been characterized by an up-and-down situation. In the early decade of 1960s, Dr. I. S. F. Ranti, assisted by Dr. Widhodho T. Karyomanggolo and associates, initiated the development of pediatric cardiology in the Child Health Department at the University of Indonesia-the Cipto Mangunkusumo Hospital (RSCM) with mission in the field of research, training, and service. At about the same time, Dr. Gan Tjong Bing and associates from the Internal Medicine Department at the same university did the same. The two groups together were succeed to conduct collaborative researches in human as well as biomedical researches in experimental animals. ${ }^{21}$ In order to increase the efficiency of service and diagnostic means, pediatric cardiology then joined with adult cardiology into a governmental institution named the National Heart Institute (Lakarnas), and function in conducting health service and research activities in the field of cardiovascular system as well as the training programs of cardiac specialist. Other figures who made their contributions in the development of the institute among others Drs. Irawan Suryo Santoso, Sukaman, Lutfi Oesman, Tagor Harahap, Surarso, and Asikin Hanafiah.

A successful cooperation with the Japanese government in the development of cardiac operations was initiated in the 1960s. The activity then was took over by the Heart Center at the RSCM and furthermore it was officially transformed into the Cardiology Department at the University of Indonesia, which continued the training programs of pediatric cardiologist as well as research and health service activities in the field of cardiovascular system. The existence of the Cardiac Hospital of Harapan Kita in 1985, with its more advanced cardiac surgical, therapeutic and diagnostic instru- 
ments, provided a great opportunity to the Department to develop its activities. With the encouragement of the Indonesian Heart Foundation, Drs. Sukaman, Surarso, Asikin Hanafiah, Lily Rilantono, Syukri Karim, Otte J. Rachman, Dede Kusmana and other senior physicians were succeed to develop their tasks, with the result that much advances has been achieved in a relatively short time. ${ }^{22}$

At the RSCM, the service of cardiovascular health for adults carried out at the Cardiovascular Care Unit by the Cardiology Division of the Department of Intemal Medicine, was initiated by Dr. Lie Keng Foei and continued by Dr. Nurhay Abdurahman and associates, whereas cardiovascular research, training and service for infants and children managed by Dr. Maemunah Affandi and staff members of Pediatric Cardiology Division of the Department of Child Health. ${ }^{21}$ The Pediatric Cardiology Division, in addition to manage patients with congenital heart malformations, also served consultations with 14 other subspecialties at the Child Health Care Unit. Cardiac operations for children, with the encouragement of the hospital's Children Heart Club and the Indonesian Heart Foundation, were conducted by Dr. Kukuh Basuki Rachmad and associates from the Thoracic Surgical Division, the Department of Surgery, and the Department of Anesthesiology..

\section{The Presence of Congenital Heart Disease in Indonesia}

Congenital diseases of the heart in infants and children are frequently found in Indonesia. Reports from various researches overseas indicated that $6-10$ of 1,000 infants born with congenital heart disease. Forms of congenital heart diseases in outline can be classified in two major groups, cyanotic and non-cyanotic cardiac malformations. Cyanotic malformations, such as tetralogy of Fallot, transposition of the great arteries, pulmonary stenosis, tricuspid atresia, and so on, are indicated by the presence of central cyanotic due to right-to-left ventricular shunt. Whereas acyanotic malformations are indicated by valvar leakage due to left-to-right ventricular shunt, among others ventricular septal defect, atrial septal defect, and patent ductus arteriosus, or the presenoe of left heart and vessel abnormalities such as aortic stenosis and aortic coerctation.

The emergence of congenital malformations of the heart can not be fully explained as yet, but it is influenced by multiple factors. There is a tendency to the emergence of several congenital malformations in a family. Patent ductus arteriosus and atrial septal defects were more frequently found in girls, while aortic stenosis more in boys. The complete formation of the fetal heart is take place at the end of first semester of pregnancy, then many factors occurred to pregnant mothers during the period are potentially amenable to cardiac malformations. The factors among others are X-ray exposures, physical and psychological traumas, as well as the use of contraceptive pills and traditional herbs. Hindrances on neural crest cells resulted in congenital 
heart disease of the conotruncal type. ${ }^{23}$ Our study indicated that there was no association between the use of contraceptive pills prior to pregnancy and the congenital malformation of conotruncal type. ${ }^{24}$

Clinical manifestations of infants and children with congenital heart disease are varied, depends on type of abnormality, degree of defect, and age of patient. Physical growth disturbance is frequently found in infants and children with congenital heart disease. Growth retardation is found in serious cyanotic and non-cyanotic malformations, while developmental retardation is generally found in cyanotic malformations. In severe malformation, patients experienced failure to thrive and often followed by recurrent respiratory tract infection. This condition could be clearly seen in patients with ventricular septal defect. ${ }^{25}$

Typical clinical signs and symptoms can be found in certain types of congenital heart disease. For example, cyanotic and squatting attacks in tetralogy of Fallot, continuous murmur in patent ductus arteriousus, widely fixed split second heart sound and soft ejection systolic murmur at the upper left sternal border in atrial septal defect, paradoxical split of the second heart sound and ejection systolic murmur in aortic stenosis, severe cyanotic in neonates particularly in head and upper extremity followed by heart failure found in patients with transposition of the great arteries. Our study indicated that typical clinical signs and symptoms of secundum atrial defect were commonly found in older children only. ${ }^{26}$

The diagnosis of congenital heart disease is based on history, physical examinations, as well as basic and advanced supporting laboratory examinations. Basic auscultatory examinations that important to congenital heart disease are chest X-ray, electrocardiographic, and routine laboratory examinations. The combination of these three examinations will increase the accuracy of clinical diagnosis. By using cardiac catheterizations and echocardiography, it became possible to increase the accuracy close to approximately $100 \%{ }^{26}$

Our experience for decades showed that cardiac catheterization and angiocardiography in infants and children was an adequately safe procedure. Correction of acid base is required in cardiac catheterization of patients with cyanotic cardiac malformations. In addition, cardiac catheterizations could also be used in intracardiac electrophysiologic examinations, among others His bundle electrocardiographic examination. ${ }^{27}$ With continuous sophisticated of echocardiographic devices, such as colorDoppler technology, besides take the role of cardiac catheterization and angiocardiography at least in part, echocardiography could also be used as the guide of balloon atrial septostomy in patients with d-transposition of the great arteries. ${ }^{2 B}$

Complications associated with congenital heart disease are congestive heart failure, cyanotic spells, infective endocarditis, thromboemboly, cerebral hemorrhage, and dysrhythmias. Our experience showed infective endocarditis that easily detected with echocardiographic devices was more frequently found in congenital malformations with valvular defects leading to significantly pressure differences, such as small VSD 
and tetralogy of Fallot. ${ }^{29}$

In principle, all cyanotic patients and a part of acyanotic patients will require cardiac surgical treatment. Algorithm, indication, and the precise time selection to surgical interventions are explicitly detailed by Rahayoe in her Dasar-dasar Diagnosis \& Tatalaksana Penyakit Jantung Bawaan Pada Anak ${ }^{30}$ Surgical closure of patent ductus arteriosus in infants has been successfully performed at the Cardiac Center of Harapan Kita Hospital in Jakarta and the Dr. Sutomo Hospital in Surabaya. ${ }^{22-31}$ However, the use of indomethacin therapy in neonates with patent ductus arteriosus, in general, is well succeed. With the advances of medical knowledge and technology, together with improvements in cardiac surgeons' skill and experience, good results of cardiac surgery at the Medical School of the University of Indonesia-Cipto Mangunkusumo Hospital became possible, ${ }^{32,33}$

\section{Rheumatic Fever Still Requires Attention}

Rheumatic fever and rheumatic heart disease are still a main problem of public health in Indonesia. Experiment data in our Department showed that significant decrease has not been made as yet in these diseases during the last ten years. Rheumatic fever is the main cause of acquired heart disease in 5-year-old children and young adults in developing countries with low socio-economic and poor environment. It is estimated that the prevalence of rheumatic heart disease in Indonesia is at 0.3 to 0.8 per 1,000 children in age of 5 to 15 years old. Major symptom that most frequently found is carditis, and the management implemented is accordance with modified Taranta $8 \%$ Markowitz procedure. ${ }^{34}$

In order to know the incidence of throat infection by group A Streptococcus betahemolyticus and rheumatic fever, coincide with the prevalence of rheumatic heart disease, we made a surveyto school children in the Subdistrict of Senen together with other researchers from the Research Center Development at the Indonesian Ministry of Health. This survey indicated that the incidence of throat infection by group A Streptocoocus beta-hemolyticus tended to decline, but the incidence of rheumatic, fever and the prevalence of rheumatic heart disease was not change compared to previous reports. ${ }^{34}$

Electrocardiography played an adequately important role in the management of rheumatic fever and rheumatic heart disease. Investigations on the sensitivity and specificity of electrocradiographic and echocardiographic criteria for left ventricular hypertrophy (LVH) were continued in our Subdivision of Cardiology, Department of Child Health, Medical School at the University of Indonesia-the RSCM in Jakarta. We found that electrocardiography was sensitive and specific enough to determine the presence of left ventricular hypertrophy. ${ }^{35}$ This finding was in contrast to earlier reports that it was not sensitive enough, although very specific, to detect $L V H$ in adult patients. 
Chest X-ray examination also played an important role in making accurate diagnosis of valvular lesion type in patients with rheumatic heart disease. In addition to plain chest X-ray examination, for the sake of diagnosis, it was generally provided with roentgenographic examination using barium at A-P and left lateral positions, so that the enlargement of specific ventricle could be detected more clearer. But, due to the poverty of patients, the examination was more often performed in standard A-P photo only. However, based on our study in patients with mitral valve lesions, standard A-P plain chest roentgen photos showed high accuracy and diagnostic index (sensitivity, specificity and predictive values) as well as a significant correlation between cardiothoracic ratio and left ventricular mass compared to echocardiography as a gold standard. $^{36}$

Mitral valvular regurgitation is a manifestation in the course of rheumatic fever, which in turn lead to rheurnatic mitral stenosis (RMS). Electrocardiographic and chest X-ray examinations played a very important role to diagnose RMS cases in peripheral areas. Our experimental results proved that electrocardiographic analysis considerably improved the prediction of RMS severity by providing high specificity and negative predictive values. The prediction of RMS severity using chest X-ray analysis also showed high sensitivity, specificity and negative predictive values. This combination of examinations with their high sensitivity value is useful to screen RMS patients in rural areas. If the negative predictive value of this combined examination is high, in other word there is no severe RMS signs on ECG nor CXR, then the RMS is most likely not severe. ${ }^{37}$

The development of echocardiographic technology, and now color Doppler echocardiography, is contributing immensely to the role of echocardiography in the diagnosis of rheumatic fever and rheumatic heart disease. There is evidence that echocardiography have a very important role in early detection of rheumatic fever and rheumatic heart disease. ${ }^{38}$

Patients are often unaware of their rheumatic fever and rheumatic heart disease previously. They, in general, came too late, so that active symptoms and signs of their disease process are not detected. As a consequence, it was this condition that made difficult the implementation for diagnostic criteria of rheumatic fever and reactive rheumatic heart disease. Our study on the implementation of revised Jones criteria showed that the criteria was not appropriate to every patients with rheumatic fever and reactive rheumatic heart disease, so that modified Jones criteria could be made in definite cases, or even the diagnosis was made merely based on clinical judgment. ${ }^{39-41}$

Our patients, in general, were people from low socio-economic and education environment. They often come with their acute and permanent valve abnormality already, even in a few cases heart failure already exist, and require medical treatment of digoxin. Therefor, we tried to look for a simple procedure to the long-term medication of digoxin. It was proven that digoxin medication that given once in a day was safe and effective. $^{42}$ 
A large numbers of patients with rheumatic heart disease experienced valvar lesions in the form of persistent mitral regurgitation. They were in need of continuous rehabilitation and revalidation efforts in order to obtain appropriate skill and knowledge for their living in community later on. We also conducted research on the use of treadmill test in patients with mitral valvular defects. It was proved that treadmill test was quite safe for patients with mild and moderate rheumatic mitral regurgitation as well as patients with older age and larger body surface area, in particular girls, tended to have shorter duration of endurance time. ${ }^{43}$

Observations for ten years were conducted in 359 patients with acute rheumatic heart disease. It was proved that their fate in the future was determined by some factors. Comparisons of survival curves based on certain characteristics showed that age at the time of of diagnosis and number of involved valves were influencing the prognosis, while nutritional, sex and parental education status were not. ${ }^{44}$

After so many years, we obtained so many experiences. More sophisticated technology could be used in the diagnosis and management of patients with rheumatic fever and rheumatic heart disease in facing the more closer globalization era, including the application of two-dimensional Doppler echocardiographic technology and interventional procedures to repair valve regurgitation using balloon catheters.

\section{Pediatric Cardiology in The Future: For Whom, Not By Whom}

At the future time, the role of pediatric cardiology will grow more and more important in the training of physicians, specialists and subspecialists in Indonesia. Pediatric cardiology is one of pediatrics' subjects that must be learned by medical students before they enter into young registrar in the Child Health Department at the seventh or eighth semester. Furthermore, they must practice their skills in the diagnosis and management of cardiovascular disease in infants and children at the ninth or tenth semester. They must be serious and diligent ${ }^{45}$ if they don't want to be eliminated by foreign physicians that would come to Indonesia in the future.

Such is the case for the training of pediatrics specialists. A mastery of skill and knowledge in pediatric cardiology must really be achieved by graduates of pediatrics specialist training programs in order to compete with their foreign counterparts. The fact shows that pediatrics specialists usually are the first to suspect the presence of heart disease in infants and children.

The service of cardiovascular disease in infants and children in Indonesia is really a big challenge in the future. Improvements in the service of hospitalized patients, outpatients, diagnostics, operations, and community extension were absolutely required with to take note of doctor-patient relationship, referral system, quality assurance, and the availability of standard procedural book of service through an integrated system. Thus, with a large number of complex cardiac malformations that we may not be cap- 
able of dealing with, it is required a cooperation by sending staffs or experts to handle complex cases.

In this connection, let me discuss several important things needed to anticipate the challenge of pediatric cardiology service in the future. In order to predict the future conditions and required measures, I will make three propositions as follows:

Firstly, cardiovascular disease will be more increase in coming years Higher level of economic growth achieved by Indonesian people in this last three decades, according to experts, will continue during the Second Phase Long-Term Development Plan. It means that people earnings will increase in next decades. On the one hand, it will lessen various infectious disease or that be result of infectious disease, and theumatic fever and rheumatic heart disease will gradually decrease. On the other hand, however, cardiovascular disease will increase with the inclination of younger patients with coronary heart disease and hypertension, like experienced by industrial countries.

Secondly, the incidence of congenital heart disease is the little bikely to decrease. Taussig, in her classic Congenital Malformations of the Heart, showed that the incidence of congenital heart disease worldwide was almost the same both in developed countries and in underdeveloped countries, i.e. between 6 to 10 of 1,000 livebirths. It means that, unless there is innovations in genetic engineering to be applied in the prevention of cardiac malformations, the incidence will not decrease in the coming years. Even, it is not impossible that the incidence will increase if the relationship between environmental factors (such as the use of medicament, pollution, radiation, earth temperature, and climate shifts) and the outcome of congenital heart malformations is true. Consequently, the need for the service of pediatric cardiology will increase more and more in coming years. ${ }^{48} \mathrm{~A}$ most conservative prediction will produce figures as shown on the table below.)

Thirdly, demands for high-quality senvice will kept increase. The presence of foreign physicians (particularly subspecialists) in Indonesia will occur sooner or later, in conjunction with the drawing near globalization and free trade era. Although we do not know fully as yet about the form of their presence, demands for this increasing health service will bring us into a less satisfying situation, that is foreign specialists would be a reference for people who need them.

These three propositions will bring us to get quickly prepared to raise our doctor's capacity in order to meet the needs of the increasing health service of pediatric cardiology. As a consequence, without reducing our respect to the role of general practitioners and family doctors in providing health service to the majority of Indonesian people, we have to prepare immediately specialists with international-standarized capacity

") This prediction is based on assumptions and considerations as follows: (1) every province at least have one pediatric cardiology consultant before the year $2020 ;(2)$ the incidence of congenital heart disease is unchanged year by year, i.e. 8 of 1,000 livebirths; (3) the incidence of rheumatic fever continued to decrease year by year; and (4) large private hospitals require fult-time pediatric cardiology consultants. 
TABLE. Projection for the need of pediatric cardiology consultants in Indonesia in the year of 2003 and 2020 (based on population data from the Central Bureau of Statistics and forecast for the growth of cardiovascular disease in infants and children in each provinces)

\begin{tabular}{|c|c|c|c|c|c|c|c|c|c|}
\hline 80 & Proulinces & $\begin{array}{l}\text { PCCs:10. } \\
1997\end{array}$ & $\begin{array}{l}\text { Ponulation } \\
\text { (tre } \\
\text { milions) }\end{array}$ & & & $\begin{array}{l}\text { Forecist lor } \\
\text { ine gowbr of } \\
\text { carcowascula } \\
\text { potients yeas }\end{array}$ & & $\begin{array}{l}\text { Proinclion } \\
\text { for the } \\
\text { pend of } \\
\text { Pcess }\end{array}$ & \\
\hline & & & 19,952 & 20,033 & 20,209 & CHat & RE 5 RHET & 2.003 & 2020 \\
\hline 1 & DI Aceh & 7 & 3.8 & 4.5 & 5.4 & 1,000 & 500 & - & 1 \\
\hline 2 & North Sumalra & $t$ & 111 & 12.5 & 15 & 3,000 & 1,500 & 3 & 7 \\
\hline 3 & West Sumatra & $t$ & 4.3 & 4.9 & 59 & 1,000 & 500 & 3 & 5 \\
\hline 4 & Riau & $=$ & 3.9 & 4.9 & 62 & 1,000 & 500 & - & 1 \\
\hline 5 & Jambi & - & 24 & 2.9 & 3.5 & 500 & 250 & $=$ & 1 \\
\hline 6 & Soulh Sumaira & $t$ & 72 & 8.6 & 10.3 & 1,750 & 875 & 3 & 5 \\
\hline 7 & Bengkulu & - & 1.4 & 1.8 & 2.1 & 350 & 175 & $=$ & 1 \\
\hline$B$ & Lampung & - & 67 & 7.7 & 92 & 1,500 & 750 & $=$ & 1 \\
\hline 9 & DKJ Jakarta & $6+5^{\circ}$ & 9.1 & 11.1 & 13.3 & 2,000 & 1.000 & 15 & 25 \\
\hline 10 & West Java & 2 & 39.2 & 45.4 & 54.5 & 10,000 & 5,000 & 3 & 5 \\
\hline 11 & Central Java & 2 & 29.7 & 32.1 & 38.5 & 7,000 & 3,500 & 3 & 5 \\
\hline 12 & DI Yogyakarla & 1 & 2.9 & 3 & 3.6 & 750 & 375 & 3 & 5 \\
\hline 13 & East Java & 3 & 33.8 & 36.7 & 44 & 8,000 & 4,000 & 5 & 15 \\
\hline 14 & West Kalimantan & $\cdot$ & 36 & 4.3 & 5.2 & 1.000 & 500 & - & 1 \\
\hline 15 & Ceniral Kalimantan & $*$ & 1.6 & 2 & 2.4 & 500 & 250 & - & 1 \\
\hline 16 & South Kalimantan & 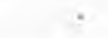 & 2.9 & 3.4 & 4.1 & 750 & 375 & $=$ & 1 \\
\hline 17 & Eası Kalimanlan & - & 23 & 3 & 3.6 & 500 & 250 & - & 1 \\
\hline 18 & Bali & 1 & 29 & 3.2 & 3.8 & 750 & 375 & 3 & 5 \\
\hline 19 & West Nusa Tenggara & - & 36 & 4.1 & 4.9 & 1,000 & 500 & $\cdot$ & 1 \\
\hline 20 & East Nusa Tenggara & * & 3.6 & 4,1 & 4.9 & 1,000 & 500 & . & 1 \\
\hline 21 & EasI Timor & * & 0.8 & 1 & 1.2 & 250 & 125 & $\cdot$ & 1 \\
\hline 22 & North Sulawesi & 1 & 26 & 3 & 36 & 750 & 375 & 3 & 5 \\
\hline 23 & Central Sulawesi & * & 19 & 2.3 & $2 . \theta$ & 500 & 250 & $\cdot$ & 1 \\
\hline 24 & Soulheast Sulawesi & $\because$ & 1.6 & 19 & 2.3 & 500 & 250 & $\cdot$ & 1 \\
\hline 25 & Soulh Sulawesi & 1 & 76 & 86 & 10.3 & 2,000 & 1,000 & 4 & 8 \\
\hline 26 & Mollucas & . & 21 & 25 & 3 & 500 & 250 & - & 1 \\
\hline 27 & Irian Jaya & $\therefore$ & 19 & 24 & 29 & 500 & 250 & . & 1 \\
\hline Tol: & & 25 & 1794 & 220.9 & 2651 & 48,350 & 24,175 & 49 & 106 \\
\hline
\end{tabular}

Notes: ${ }^{1} \mathrm{PCCs}=$ Pediatric cardiology consultants, including cardiac and arterial specialists dedicated to pediatric cardiology; ${ }^{2}$ According to the Inter-Census Population Survey (Supas) of $1995 ;{ }^{46}{ }^{3}$ Based on projection of population per province in $1990-2000 ;{ }^{47}{ }^{4} \mathrm{CHD}=$ Congenital Heart Disease ${ }^{5} \mathrm{RF}=$ Rheumatic Fever; ${ }^{6} \mathrm{RHD}=$ Rheumatic Heart Disease. 
(or at least regionally) as well as subspecialists with similar qualification. It seems that, in pediatric cardiology, the availability of pediatric cardiology consultants can not be delayed anymore. Pediatric cardiology consultants must be spread in every province hospitals and other hospitals in big cities nationwide.

In order to bring about the objective immediately, it is time for us to join our available potentials and to prepare human resources in pediatric cardiology. What we must bear in mind is children who need pediatric cardiologists are not live in Jakarta and Surabaya only, but scattered nationwide. We must see that the need for adequately treatments can not be conducted only two or four times a year, but must available evenly all year long. The majority of patients are impossible to be referred to hospitals that far from their home because of their financial limitedness as well as physical conditions. There is no more reasonable answer, I think, than to provide pediatric cardiology consultants to children as near as possible, at least in provincial capitals.

When there may be some debates in the past between pediatric cardiologists and cardiac surgeons about who have the right to treat Tom that suffered from theumatic heart disease or Dick from tetralogy of Fallot, it is only fitting that we felt tired of argue. Instead of wasting time and energy to argue, it is better for us to focus our available resources immediately toward the availability of pediatric cardiology consultants (or pediatric cardiology specialists, or whatever it is).

I don't want to discuss technical problems further, but I want to apply for the national importance (read: for the sake of children with cardiac malformations) must be the main orientation in every our steps. It is hard to forgive ourselves if we disavow it again in any reasons anyway. Thank God, the gladden wind of change is blowing to us: now. At the present time, we heard comfortable voices louder and louder that pediatric and cardiac and arterial specialists attracted to pediatric cardiology will discuss passionately in cardiac catheterization room or in the Intemet screen someday. I will be one of the first to nodd if somebody ask me whether it is just a matter of time,

\section{Research in Pediatric Cardiology in The Future}

In recent years, molecular biology and genetic approaches are regarded as the pioneer in the biomedical sciences, including in the field of pediatric cardiology. However, the fact remains that the development of genetics and molecular biological reseanches in the field of cardiology is muchslower than in other fields. This is due to the characteristics of the myocardium that, until a few years ago, have made the heart less than ideal for a biomolecular research. The reason is because of the vital role of the organ; and genetic mutations, that required in any genetics and molecular researches, are lethal early in fetal life and, therefore, the research can not performed. This is in contrast to the large number of mutations in immupology, hematology, endocrinology, hepatology, microbiology, etc. In addition, obtaining repeated samples of the myocar- 
dium from the living individual is hard to performed. The two factors, together with some other factors, were responsible for delaying the development of basic research in cardiology that extremely required in order to elucidate various essential questions on physiologic and cardiovascular pathophysiologic states. However, recent advances of molecular biology has eroded a part of the opinion; therefore, it has provided the great opportunity for accelerating the basic research that minimalizing the gap between molecular biologic significance in the cardiovascular system and in other systems. ${ }^{16}$

The opinion is a challenge for pediatric cardiologists. In general, pediatric cardiologists are not provided with the technical abilities of biomolecular research; thus, it is clear that pediatric cardiologists and other researchers in the basic sciences have to perform collaboration in order to develop the basic sciences and to elucidate the basic questions. Above of all, the performance of biomolecular researches couldn't be regarded as a 'side job'. It shoud be bome in mind, at this context, a pediatric cardiology consultant in the first place must be a clinician, who should gave priority to clinical skills and professionalism in the management of patients with congenital heart disease. Consequently, clinical investigations that are directly benefit to clinical practices must be continually developed and, at the end, the implementation of medical science and technology will be the main measuring rod whether the science is useful to raise the welfare of human being or not. The explanations mentioned above bring a heavy responsibility and commitment both for myself and the experts of the subspecialty to answer the challenge.

\section{References}

1. H.M. Soeharto. Pidato Kenegaraan Presiden Republik Indonesia di depan sidang Dewan Perwakilan Rakyat, 16 Agustus 1996.

2. Survei Kesehatan Rumah Tangga (SKRT) Republik Indonesia tahun 1996.

3. Ismael $\mathrm{S}$. Tumbuh kembang anak dalam pencapaian potensi sumber daya manusia yang tangguh. Pidato pengukuhan guru besar tetap dalam ilmu kesehatan anak. FKUI, Jakarta, 5 Oktober 1991.

4. Emmanouilides GC. The development of pediatric cardiology: Historical milestones. In: Emmanouilides GC, Riemenschneider TA, Allen HD, Hutgesell HP, eds., Moss and Adams heart disease in infants, children, and adolescents, edisi ke 5. Baltimore: Williams \& Wilkins; 1995: xxi-xxiv

5. Australian-New Zealand Cardiac Society. The Committee for Higher Training in Pediatrics of Royal College of Physician, 1995.

6. Williams RG, Kennedy TL, Moller JH. Pediatric cardiology in the 1990. JACC, $1994 ; 23: 977-80$.

7. Burg FD, Process of education for pediatric subspecialist. In: Pediatric education for subspecialist. University of Pensylvania School of Medicine USA, 1990.

8. Hess J. Pediatric cardiology in Netherlands. Cardiol in the Young, 1995; 5:3-5. 
9. National Heart \& Lung Institute University of London. Diploma in pediatric cardiology, 1994.

10. Moller JH. Fifty years of pediatric cardiology and challenges for the future. Alexander S. Nadas lecture. Circulation, 1994; 89:2479-83.

11. British Paediatric Cardiac Association. Guidlines for specialist training paediatric cardiology. Heart 1996; 75:534-6.

12. Nadas SA. Foreword. In: Fyler DC, eds,, Nadas' Pediatric cardiology, 1st ed., Singapore: Hanley \& Belfus, 1992: xiii.

13. Clardk EB, Takao A. Developmental cardiology. Morphogenesis and function; 1 st ed. New York: Futura Publíshing Company; 1990:xiii.

14. Castaneda AR, Jonas RA, Mayer JE, Hanley FL. Cardiac surgery of the neonate and infant. Philadelphia: WB Saunders Co., 1994.

15. Tabbutt S, Perry SB. New developments in intracardiac and intravascular devices for congenital heart disease (review article). Curr Opin Cardiol 1996; 11:61-7.

16. Nadal-Ginard B, Mahdavi V. A celular and molecular approach to pediatric cardiology. In: Fyler DC, eds., Nadas' Pediatric cardiology; 1st ed, Singapore; Hanley \& Belfus, 1992:747-59.

17. Rilantono LI. Peran riset dan pengembangan IPTEK adalah tuntutan nasional untuk penanggulangan masalah kardiovaskular. Pidato pengukuhan guru besar tetap Kardiologi, FKUI, Jakarta, 18 Juni 1994.

18. Bao W, Srinivasan SR, Watigney WA, Bao W, Berenson GS. Usefulness of childhood law-density lipoprotein cholesterol level in predicting adult dyslipidemia and other cardiovascular risks. The Bogalusa heart Study. Arch Intern Med 1996; 156:1315-20.

19. Strong WB, Deckelbaum RJ, Giddding SS, Kavey RW, Washington R, Wilmore $\mathrm{JH}$, Perry CL. Integrated cardiovascular health promotion in childhood. In:: Gessner IH, Victoria BE, eds. Pediatric cardiology. A problem oriented approach. Philadelphia : WB Saunders, 1993; 203-20.

20. Riemensneider TA. The practice of pediatric cardiology. In: Emmanouilides GC, Riemenschneider TA, Allen HD, Hutgesell HP, eds. Moss and Adams heart disease in infants, children, and adolescents; 5 th ed. Baltimore: William \&6 Wilkins; 1995: 1804-11.

21. Karyomanggolo WT, Ismael S, Sastroasmoro S, Soedjatmiko, Rusli DS. 60 tahun pendidikan dokter spesialis anak di Indonesia. Majelis Pembina dan Penilai Dokter Spesialis IDAI. Jakarta: Pustaka Kartini, 1995.

22. Rachman OJ. Personal communicationn, 1996.

23. Fujii T. A Possible involvement of neural crest cells in drug-induced alterations of cardiovascular function. In: Clark C, Development cardiology, morphogen and function. New York: Futura Publishing, 1990; 147-58.

24. Sastroasmoro S, Nurhamzah W, Madiyono B, Oesman In, Putra ST, Association between maternal hormone exposure and the development of congenital heart disease of the conotruncal type. A case-control study. Paediatr Indones 1993; 33:291-300. 
25. Madiyono B, Soelaeman EJ, Oesman IN, Sastroasmoro S. Physical growth of children with ventricular septal defect. Paediatr Indones 1994; 34:16-25.

26. Madiyono B, Achmad J, Sastroasmoro S, Oesman IN, Putra S. Clinical features and management of secundum atrial septal defect in infant and children. Med J Indones 1996; 5:42-8.

27. Madiyono B, Trisnohadi HB, Affandi MB. His bundle electrocardiogram in children with secundum atrial septal defect. Paediatr Indones $1981 ; 21: 1-10$.

28. Sastroasmoro S, Madiyono B, Oesman I N, Putra ST. Transumbilical baloon septostomy with echocardiographic monitoring. Paediatr Indones 1988; 28: 160-6.

29. Sastroasmoro S. Madiyono B, Oesman IN, Putra ST. Bacterial endocarditis in children: Clinical and laboratory findings and the role of echocardiography in its diagnosis and management. Paeciatr Indones 1989; 29:188-98.

30. Rahayoe AU. Indikasi dan pemilihan waktu yang tepat untuk intervensi penyakit jantung bawaan. In: Putra ST, Advani N, Rahayoe AU, eds. Dasardasar diagnosis dan tata laksana penyakit jantung bawaan pada neonatus. Pendidikan Kedokteran Berkelanjutan IKA XXXII, hal. 202-12. Jakarta, 1994.

31. Ontoseno T. Pengalaman kardiologi intervensi pada bayi dan anak di RS Sutomo, Surabaya. In: Sastroasmoro S, Madiyono B, Putra ST (eds). Pengenalan dini dan tatalaksana penyakit jantung bawaan pada neonatus. Naskah lengkap Pendidikan Kedokteran Berkelanjutan Ilmu Kesehatan Anak XXXII, hal. 202-12, Jakarta 1-2 Juli 1994.

32. Madiyono B, Oesman IN, Sastroasmoro S, Putra ST, Rachmad KB, Patent ductus arteriosus before and after surgery. Paediatr Indones 1989; 29:39-51.

33. Madiyono B, Oesman IN, Sastroasmoro S, Putra ST, Soelaeman EJ, Rachmad KB. Secundum atrial septal defect before and after surgery. Paediatr Indones $1989 ; 29: 199-208$.

34. Madiyono B. Epidemiologi penyakit jantung reumatik di Indonnesia. J Kardiol Indones 1995; 200:25-33.

35. Sastroasmoro S, Madiyono B, Oesman IN. Sensitivity and specificity of electrocardiographic criteria of left ventricular hypertrophy in children with rheumatic heart disease. Peadiatr Indones 1991; 31:233-44.

36. Madiyono B, Sugiarno 1, Putra ST, Sastroasmoro S, Karyomanggolo WT, Pramulyo HS. Diagnostic value of plain chest roentgenogram in rheumatic mitral valvular disease. Paediatr Indones 1996; 36:102-9.

37. Oesman IN, Gunardi H, Madiyono B, Sastroasmoro S, Putra ST. Profile and prediction of severety of rheumatic mitral stenosis. Med J Indones 1996; 5:152-7.

38. Putra ST, Sastroasmoro S, Madiyono B, Oesman IN. Echocardiographic diagnosis of acute rheumatic fever in children. Paediatr Indones 1993; 33: 227-31.

39. Madiyono B, Sastroasmoro S, Oesman IN, Putra ST, Advani N. The diagnosis of rheumatic fever. Which modification Paediatr Indones 1994; 34:141-8.

40. Madiyuno B. Tata laksana masalah kardiologi anak. Bagian II. Demam reumatik dan gagal jantung. Sari Pediatri 1994; 1:147-54. 
41. Madiyono B. Penatalaksanaan demam reumatk pada anak. In: Matondang CS, Akip AAP (eds). Strategi pendekatan klinis berbagai penyakit alergi dan reumatik pada anak. Naskah Lengkap Pendidikan Kedokteran Berkelanjutan IImu Kesehatan Anak XXXVI, hal. 76-87, Jakarta 10-11 Nopember 1995.

42. Madiyono B. Pemantauan kadar digoksin pada penyakit jantung reumatik dengan gagal jantung. J Kardiol Indones 1994; 19:200-6.

43. Madiyono B, Rusdi S, Oesman IN, Sastroasmoro S, Advani N. Treadmill test in patients with rheumatic mitral regurgitation. Med J Indones 1995; 4:247-53.

44. Sastroasmoro S, Oesman IN, Madiyono B, Putra S. Survival patterns of children with rheumatic heart disease. Med J Indones 1995; 4:254-63.

45. Paul RW. Critical thinking. How to prepare students for a rapidly change world. In: Wilson J, Binker AJA, eds.. Santa Rosa: Foundation for Critical Thinking, 1993.

46. Biro Pusat Statistik. Survei Penduduk Antar Sensus (Suspas) 1995.

47. Biro Pusat Statistik. Proyeksi Penduduk Indonesia per Propinsi 1990-2000.

48. Kartasasmita G. Masyarakat Indonesia di tahun 2020. Tantangan bagi pendidikan tinggi kesehatan. Badan Perencanaan Pembangunan Nasional. Dies Natalis ke-48 Fakultas Kedokteran Universitas indonesia di Jakarta, 4 April 1997. 